\title{
Crime, Justice, and Growth in South Africa: Toward a Plausible Contribution from Criminal Justice to Economic Growth
}

\author{
Christopher Stone
}

CID Working Paper No. 131

August 2006

(C) Copyright 2006 Christopher Stone and the President and Fellows of Harvard College
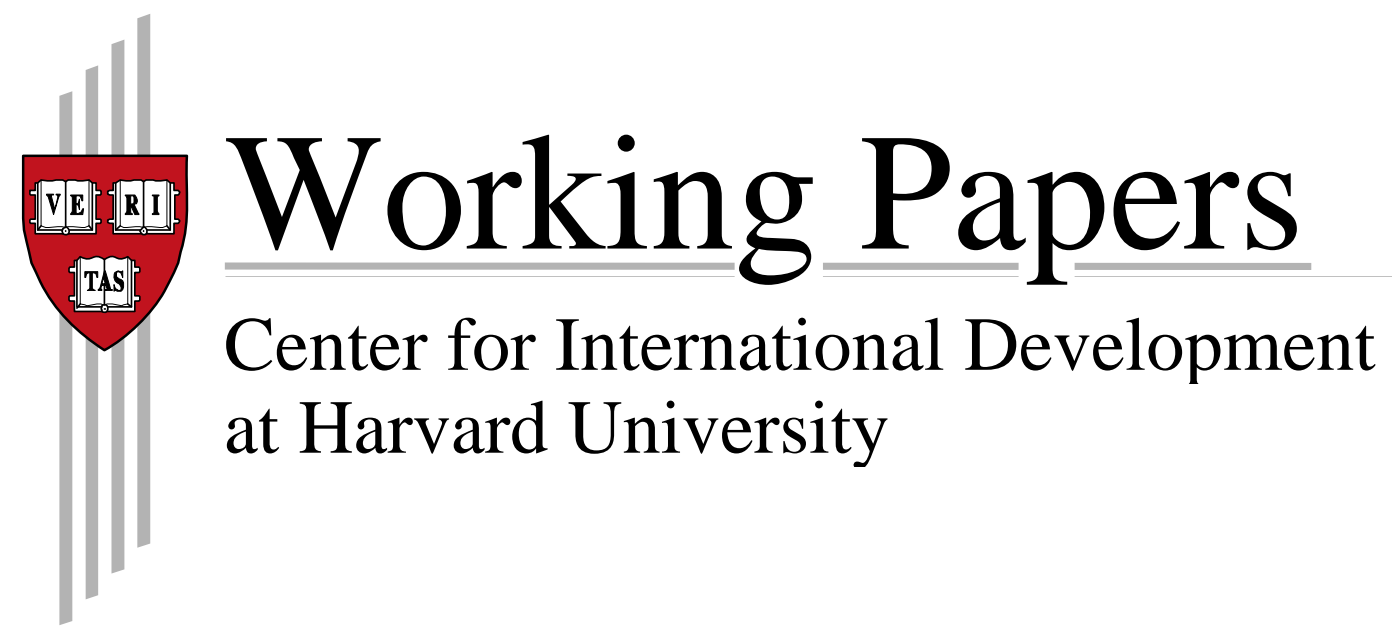


\title{
Crime, Justice, and Growth in South Africa: Toward a Plausible Contribution from Criminal Justice to Economic Growth
}

\author{
Christopher Stone
}

Revised 25 August 2006

\begin{abstract}
Crime in South Africa is high and widely believed to restrain investment. Nevertheless, both the mechanisms through which crime constrains growth and the actions that might be taken to loosen its grip are poorly understood. In light of the limited knowledge in the field and the limited capacity of criminal justice institutions, this paper proposes focusing on two issues: (1) the costs of crime to business, especially householdbased enterprises in low-income settlements, and (2) the perception of violent crime. In both cases, the paper proposes a cyclical process of iterative innovation in which government seeks to solve narrowly circumscribed crime problems, and then leverages each success to generate wider hope and confidence in the criminal justice system.
\end{abstract}

Keywords: South Africa, crime

JEL Codes: 055, K42

This paper is part of the South Africa Growth Initiative. The Center for International Development has convened an international panel of economists and international experts from Harvard University, the Massachusetts Institute of Technology, the University of Michigan, and other institutions to work with South African economists to study that country's constraints to and opportunities for accelerated growth. This project is an initiative of the National Treasury of the Republic of South Africa within the government's Accelerated and Shared Growth Initiative (ASGI-SA), which seeks to consolidate the gains of post-transition economic stability and accelerate growth in order to create employment and improve the livelihoods of all South Africans.

The author is Daniel and Florence Guggenheim Professor of the Practice of Criminal Justice at the Kennedy School of Government, Harvard University. This is an interim revision of a draft paper originally presented at a workshop convened by the National Treasury of South Africa in July 2006 to discuss “A Growth Diagnostic.” This revision has benefited greatly from the insightful comments and criticisms of Antony Altbeker, as well as discussion with Azhar Catchalia, Zohra Dawood, Desiree Daniels, Johannes Fedderke, Todd Foglesong, Darwin Franks, Rudolf Gouws, Sandy Johnston, Antoinette Louw, Emma Mackinnon, Lebogang Montjane, Connie Motshumi, and Eric Pelser. The author is especially grateful for the continuing cooperation of Kay Brown, Chris de Kock, Willie Hofmeyr, Vusi Pikoli, and Jackie Selebi. 


\section{Introduction}

Generating equitable economic growth is a priority for the government of South Africa, and the high level of violent crime in the country is frequently mentioned as a constraint on growth. But are high levels of crime a real constraint on growth? And, if so, is there a crime and criminal justice policy that the government could implement that would reduce this constraint in the near term?

These same questions are on the minds of government officials and development specialists beyond South Africa. International financial institutions, such as the World Bank, are reconsidering their policies on funding for police and criminal justice reform, just as bilateral and multilateral development agencies, such as the UK's Department for International Development and the United Nations Development Program, are themselves assessing the links between crime, criminal justice, and poverty reduction. Increasingly those interested in the dynamics of economic development are asking similar questions: how does high crime constrain growth and are there practical criminal justice reforms that might reverse the process?

The answer to both questions is yes. Crime does constrain growth and there are things government might do about it; but that answer has three caveats.

First caveat. While there is broad agreement that high levels of violent crime constrains growth, there is very little known about how it does so and by how much. In the World Bank's most recent Investment Climate Survey, 30 percent of enterprises in South Africa rated crime as a major or very severe constraint on investment, putting crime among the four most frequently mentioned constraints. (World Bank, 2005). ${ }^{1}$ A study of growth across several Brazilian cities finds that a ten percent increase in baseline homicide rates reduces city growth by 1.1 percent over the next decade (da Mata, et al., 2005). And Glaeser (2005) has found that "high murder rates are associated with low growth rates" across U.S. cities. The South African government itself routinely lists the high level of crime, particularly violent crime, as an impediment to growth. ${ }^{2}$ Yet the evidence is much weaker about specifically how crime constrains growth. On this question, there are many hypotheses and few certainties. ${ }^{3}$

\footnotetext{
${ }^{1}$ The report puts the 30 percent figure in perspective. "This compares favorably with the more volatile Latin American countries, where between 50 and $80 \%$ of firms rate crime as a severe obstacle, but is considerably higher than most other middle-income countries (between 10 and $20 \%$ of enterprises).”

${ }^{2}$ In his annual report for the year ending in March 2003, the National Commissioner of the South African Police Service identifies high levels of unemployment as a major cause of crime, but he also says that violent crimes "project an extremely negative image abroad" and "inhibit confidence, investment, and tourism" (South African Police Service, 2003, pp.24-26).

${ }^{3}$ Perhaps the most rigorous effort to date to model the impact of crime on growth in South Africa finds that the direct impact of crime on growth is difficult to detect. Instead, crime seems to affect growth indirectly by contributing to a perception of instability. See: both available as working papers at www.econrsa.org.
} 
Second caveat. The policies available to governments anywhere to reduce crime are relatively crude. The contribution of prosecutors, judges, prisons, and even police to the control of the overall level of crime in any country is a matter of great uncertainty. These institutions may reduce crime, but they may also exacerbate it. Indeed, they may do both at the same time, even while the combined effects are overwhelmed by factors entirely outside the criminal justice system. The available evidence is too weak to explain why crime rates rise or fall in a city, province, or nation over a year or more. As James Q. Wilson-an early American proponent of strict responses to crime-has written recently:

There is no silver bullet that will reduce crime, much less eliminate it.... [N]o one can satisfactorily explain changes in crime rates.... ${ }^{4}$

What crime and justice policy can do successfully, at least some of the time, is reduce specific crimes in specific places. The challenge here is to find pathways that allow solutions to specific crime problems to loosen specific crime-constraints on growth.

Third caveat. Economic growth should not become the primary goal of crime policy. Reducing crime and delivering justice are obligations in their own rights for any government. Growth will necessarily be a secondary goal for the justice system.

Still, thinking seriously about contributing to equitable economic growth can be a healthy exercise for police, prosecutors, judges, and corrections officials. Not only could equitable growth help relieve the poverty and inequality that seem to fuel much crime, but putting crime policy in the service of economic policy might open up new ways of thinking in the justice sector. There is a certain arrogance that accretes among those who make crime policy to the point that they begin to think that preserving public safety and administering justice are the highest obligations of the state, and that every other part of government - from the education department to the finance ministry-should contribute to these goals wherever possible. It would be a useful discipline to reverse this thinking: to ask what it means for law enforcement to contribute to growth and to thereby help reduce unemployment.

With those three caveats, this paper takes seriously the challenge of crafting a pro-growth crime policy in South Africa. After a brief review of the nature of crime in South Africa, the paper examines several purported links between crime and growth, settling on two links worth testing. The paper then considers how some specific initiatives might be taken forward. Parts of the criminal justice system in South Africa appear committed to

\footnotetext{
${ }^{4}$ Wilson expands on this point: “No one, so far as I am aware, has ever explained a nation's crime rate by taking systematically into account all of the variables that might affect it. (Unfortunately, this inability has not prevented some scholars from confidently explaining to journalists why the crime rate has gone up or gone down.) Moreover, it is no simple matter to drive down crime rates by relying more on imprisonment. Doing that requires changing the effectiveness of policing, altering the behavior of prosecutors and judges, and coping with the costs, tangible and intangible, of having a large prison population. The same problems confront efforts to reduce the crime rate by means of prevention, employment, and rehabilitation programs. We are getting better at evaluating such efforts and drawing lessons from them, but we have no idea what would be the cumulative effect of putting in place all of the best programs on a large scale.” James Q. Wilson, "Crime and Public Policy" in Wilson and Petersilia (eds.) Crime: Public Policies for Crime Control, Institute for Contemporary Studies, 2004, pages 537-38 and 546-47.
} 
moving in this direction, exemplified in the National Prosecuting Authority's stated goal of contributing to stronger economic growth. Yet officials have only just begun to think rigorously about how the justice sector might support the country's ambitions for "shared growth.” This paper joins in that nascent discussion.

\section{Violent Crime}

South Africa has such a wide reputation for high crime that it is useful to begin any serious discussion by pointing out that the rates for most crimes in South Africa are not outside international norms. Consider, for example, the overall rate of criminal victimization. The latest serious victimization study in South Africa, completed in 2003, shows a one-year victimization rate of 22.9 percent, down from $24.5 \%$ in 1998 . (Burton et al., 2004) This compares favorably with a victimization rate in England and Wales of 26.7\% in 2003 (Clegg et al., 2005). Yes, a large fraction of South African households experience crime every year, but not any larger a fraction than in many rich counties.

The distinctive feature of crime in South Africa is not its volume but its violence. ${ }^{5}$ The homicide rate presents the extent of violence most starkly. Although the rate has declined substantially since 1994 when South Africa recorded 67 murders per 100,000 people; it was last reported through March 2005 to be at 40.3 per 100,000, among the highest national rates in the world. There is some variation among provinces, but the murder rates across all of South Africa are high, especially in the Western Cape and KwaZulu-Natal.

It may be useful to contrast the situation in South Africa with that in one of the most violent rich countries of the world: the United States. The murder rate in the United States is less than one-sixth that of South Africa, but that comparison is hardly fair. More instructive is the comparison between the most violent places in the two countries. There are places within the United States, for example, where the murder rate has recently been similar to South African levels: Washington, DC., Baltimore, and New Orleans (see Figure 1).

\footnotetext{
5 The National Commissioner for the South African Police Service makes the same point in his annual report for 2002-2003 when he writes that "South Africa is not generally more crime-ridden than Australia, Canada, or New Zealand. The real problem is the abnormal violence associated with our crime.” (South African Police Service, 2003, p.26).
} 


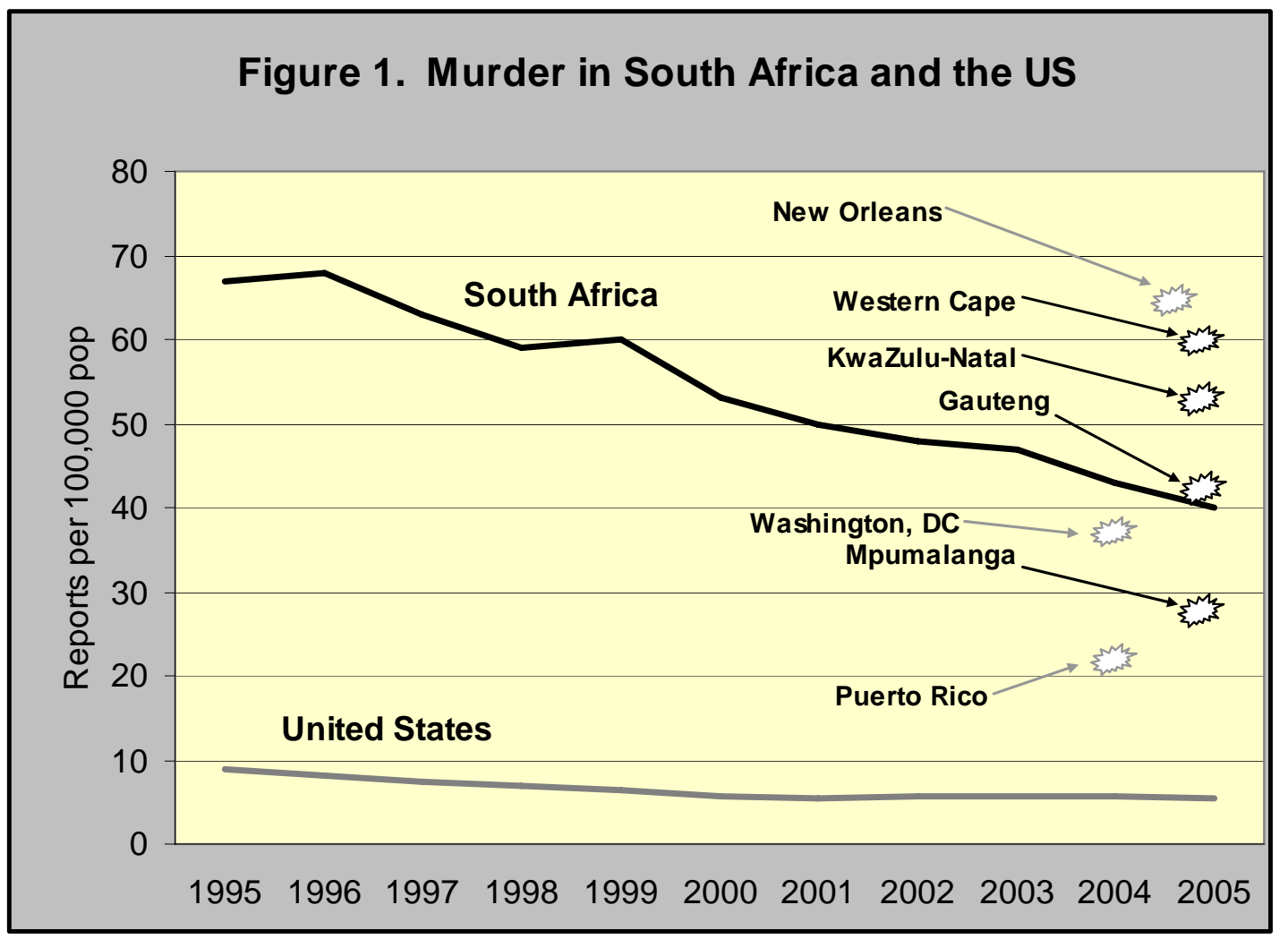

While journalists and statisticians focus on homicides because of their human interest and the relatively good quality of the statistics, robbery may be a more telling crime for South Africa. South Africa's rate of robberies reported to the police is roughly double the rates in the U.S. states with the highest rates of robbery, and the difference is probably larger because of the low level at which South Africans report robberies to the police (Figure 2). ${ }^{6}$

\footnotetext{
${ }^{6}$ According to the 2003 victimization survey, 29 percent of victims of robbery in South Africa reported the crime to the police. Burton, et al. (2004), pp.131-38.
} 


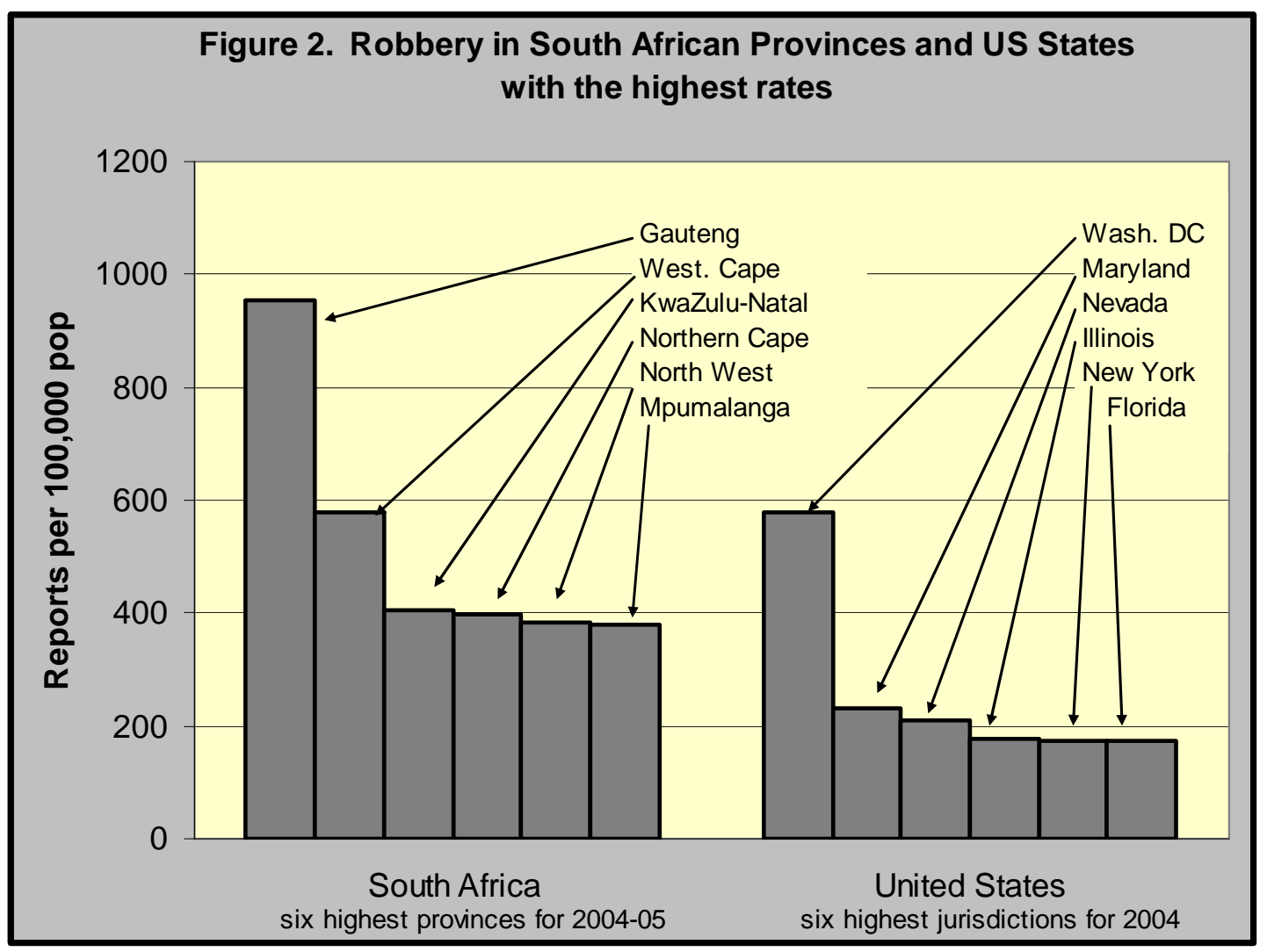

Rape is also reported far more frequently in South Africa, at rates two-to-three times the level of the U.S. states with the highest rates. In contrast, rates of serious assault in South Africa seem to be roughly similar and to those in the U.S. states with the highest rates (Figure 3). 


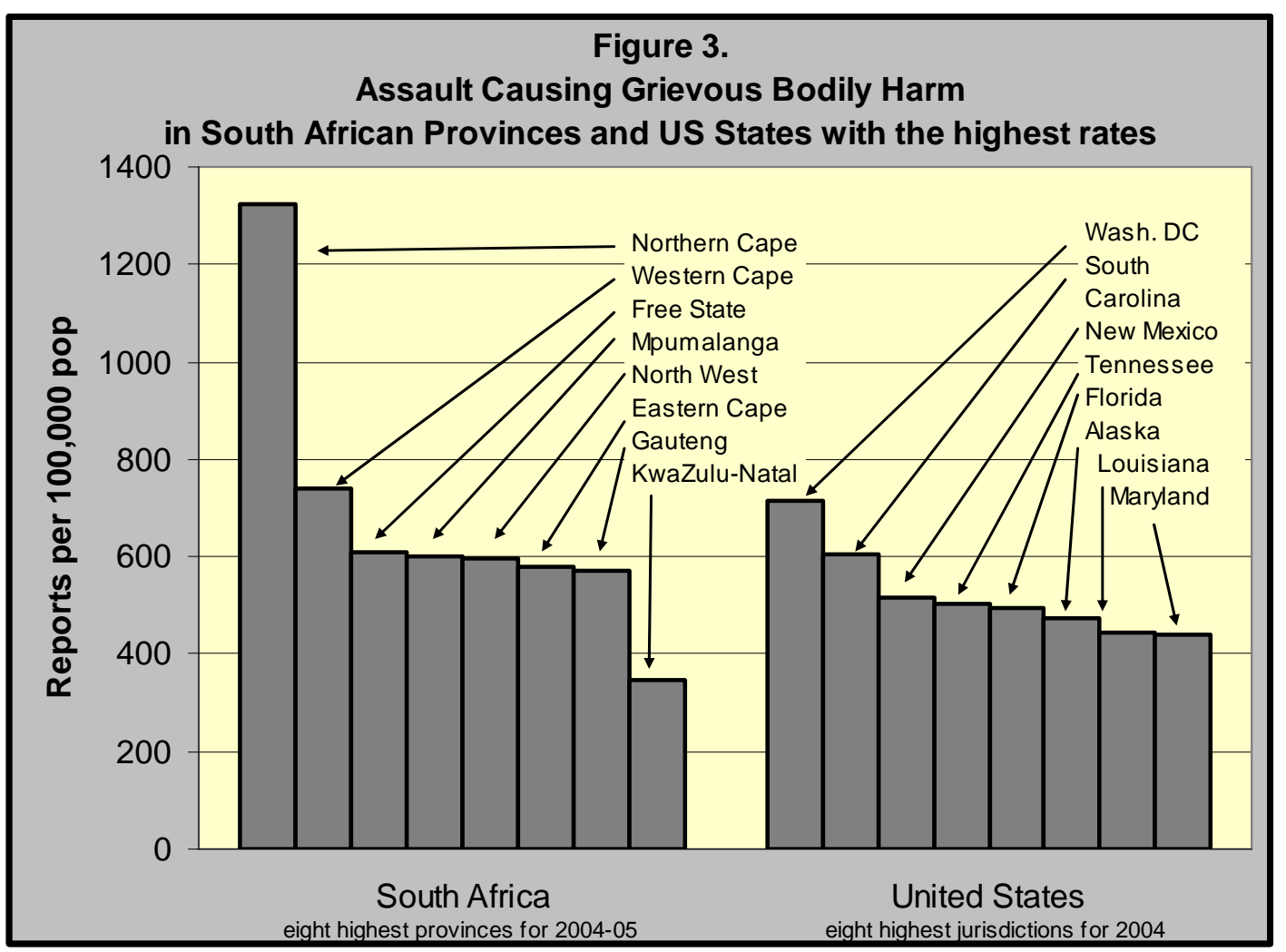

At least one additional feature of crime in South Africa deserves attention in a general overview: the frequency of housebreaking. In 2003, a representative sample of South Africans rated housebreaking as the crime they most feared after murder, of greater concern than robbery or assault. Both police statistics and the 2003 victimization survey show that housebreaking is the most frequent of all the serious crime recorded, although it is not one of the crimes given priority by the police service. ${ }^{7}$

In sum, the distinctive feature of crime in South Africa is its violence rather than its volume. Three categories of violent crime are especially frequent by international standards-murder, robbery, and rape-with housebreaking generating comparable levels of fear as these.

While these crimes are horribly frequent, they are not at levels beyond the capacity of police and justice officials to address and, with some luck, reduce. The specific methods by which the South African Police Service, the National Prosecuting Authority, the Department of Correctional Services, and the Department of Social Welfare are attempting to reduce crime in South Africa are beyond the scope of this paper, as are the various sentencing statutes and other legislative reforms that Parliament has enacted in response to crime. Whatever the successes and failures to date, more clearly needs to be done. It should suffice here to briefly review current thinking in the field globally about how governments can most usefully tackle these kinds of serious crime.

\footnotetext{
${ }^{7}$ Housebreaking is not prioritized by the South Africa Police Service in its National Crime Combating Strategy. See Burton, et al. (2004), pages 120-124.
} 
Just as there are no silver bullets for reducing national crime rates, there are no sure-fire recipes for reducing specific crimes. There is, however, a growing consensus that a disciplined process of experimentation, assessment, and then larger experimentation-a process of iterative innovation - can greatly improve the chances that government will bring crime down, especially when that process includes certain elements. Those key elements begin with the careful analysis of specific crime patterns (including attention to minor offenses), the development of experimental interventions that engage multiple government departments all targeting the same specific crime patterns, close to real-time (computer-assisted) management and accountability tools, and certain kinds of partnerships between law enforcement and the public (both businesses and community residents). There is evidence from New York, Chicago, and Boston in the United States, from Sao Paulo and Belo Horizonte in Brazil, and from several cities across Peru, to mention just three countries with more than their share of violence, that this process of iterative innovation can both reduce particular crime problems and reduce public concern about those problems. ${ }^{8}$ In short, while there is no formula for reducing violent crime, a criminal justice system has a fighting chance when it begins by identifying particular patterns and experiments rigorously with a variety of responses.

Enough generalities. What are the specific crime patterns that might be constraining South Africa's growth, and how might the safety and justice sector begin to address these?

\section{Crime and Growth}

There is a lot of general writing about the causal, or at least logical, pathways by which crime can restrain economic growth. For example, in the introduction to a recent World Bank paper on crime and inequality in South Africa, Demombynes and Özler (2002) begin with a litany of how crime "may" restrain growth:

The threat of crime diverts resources to protection efforts, exacts health costs through increased stress, and generally creates an environment unconducive to productive activity. Additionally, the widespread emigration of South African professionals in recent years is attributable in part to their desire to escape a high crime environment. All of these effects are likely to discourage investment and stifle long-term growth in South Africa. [page 2]

Perhaps. Passages like this one adorn many World Bank reports, presenting a parade of plausible but only weakly supported arguments. ${ }^{9}$ The purpose of these assertions does

\footnotetext{
${ }^{8}$ See, for example, Wesley G. Skogan and Susan M. Hartnett, Community Policing: Chicago Style, Oxford University Press, 1999, for an excellent example of how specific strategies reduced the perception of crime as a problem.

${ }^{9}$ Two recent examples should more than suffice to illustrate the style. The first comes from a Country Economic Memorandum for the Dominican Republic, and its chapter on "Crime and Its Impact on Growth":

Firms' and households' perceptions of increased crime are reflected in rising victimization rates which have both direct and indirect impacts on growth. For firms, production and profits are diminished by losses or damage from robbery or other crimes, and by crowding out investment
} 
not appear to be to sharpen understanding of the factors restraining growth, but rather to justify the devotion of attention (and resources) generally to problems of crime and the administration of justice. If we want to understand more specifically where public policy, law enforcement, and the administration of justice might effectively intervene to reduce the drag on growth that crime might cause, we need to unpack these assertions. We need to examine each mechanism, distinguishing the specific crimes that are hypothesized to create specific effects, and noting where fear of crime or cynicism about government is the real focus, rather than specific instances of criminal behavior.

The mechanisms by which it is commonly asserted that crime restrains growth can be grouped under seven broad themes:

1. Crime imposes costs on business (direct losses plus the costs of security and prevention) that reduce profits and divert funds that could be invested in productive capacity.

2. Crime induces government to spend money on law enforcement, crime prevention, and the administration of justice that would otherwise be available to stimulate growth.

3. Crime induces households to spend money on health care and security precautions rather than on school fees and other investments

4. Crime erodes human capital by encouraging emigration and by injuring and killing skilled workers

5. Crime keeps workers out of the labor market by discouraging them from accepting jobs in off-hours and far from home

6. Crime discourages foreign investment

7. Crime disrupts schooling and other public investments to support long-term growth (such as public transport), blunting the effectiveness of these investments

Each of these assertions has some plausible core, and one can easily imagine anecdotal evidence in support of each. But the statements are also questionable on their face, and-

due to high spending on prevention measures. Crime also reduces long-run GDP growth by discouraging new investment due to the perceived risk of losses, diverting government spending from more productive uses to security expenditures, increasing incentives for migration, human capital losses due to injury or murder, and worse schooling outcomes. At the individual level, household spending on protection or health services for crime related injuries may displace spending on school fees, for example, and high crime rates may keep workers out of the labor force.

A second example comes from a World Bank (1997) report on Violence and Poverty in Jamaica which explains:

The impact of violence at the macroeconomic level is apparent, although difficult to quantify. For example, the tourism industry and the ability of Jamaica to attract overseas investors, especially Jamaicans abroad, is affected by press reports of violence. Although the statistical relationship between violence (measured in the numbers of murders per year) and tourist arrivals is inconclusive, the tourism industry is particularly sensitive not only to changes in Jamaican and international investor confidence, but to the image projected of the island to potential vacationers....By the same token, violence has no doubt been a contributory factor to the migration of Jamaicans — and their capital—out of Jamaica. 
even if true - might not lend themselves to any practical intervention. Consider, for example, the assertion that high crime prevents some people for accepting work that would require working late at night or traveling long distances in places where the risk of crime is high. Plausible, but in my discussions with South African business leaders and criminologists, this assertion has been widely questioned, with my discussants noting that many occupations in South Africa entail great personal risk, and yet the ranks of those willing to take risky jobs (from coal mining to private security) is long. Carefully worded surveys could provide useful insight about the trade-offs that the unemployed make between jobs and the risk of crime, but we do not yet have those data.

What we do have are a series of studies examining a related hypothesis that women's experience of domestic violence would have negative consequences for their participation in the work force. Like the assertions listed above, the link between domestic violence and decreased labor force participation is plausible. Lloyd (1997) reviews several studies that concluded that male violence or intimate partner abuse limited women's employment and employability. In one study of working women who sought counseling from victim services and in a second study that interviewed battered women in shelters, researchers reported that many women lost jobs, missed work, and arrived late because of their experience of violence.

But when Lloyd and others set out to measure more rigorously the impact of domestic violence on women's employment, they found little evidence of any special effect. Yes, women who are victims of domestic violence are late to work, miss work, and lose jobs; but these are mostly poor women facing many obstacles to stable employment, and their counterparts who do not report domestic violence have the same problems maintaining employment. As Lloyd (1997) concludes:

Current employment status appears unaffected by women's varying experiences of male aggression in intimate relationships.... [I]n a low income neighborhood, women who can obtain work do, whether or not they experience domestic violence.... While some women who experience abuse seem less likely to enter or stay in the labor market, the labor force participation of others who experience domestic violence appears to be either relatively unaffected or positively affected. [p. 156]

A later, re-analysis of the data came to the same conclusion (Lloyd and Tulac, 1999). ${ }^{10}$ The lesson here is that plausible stories about the harm that crime causes do not always prove to be true. If we are committed to prosecuting cases of domestic violence, the fact that doing so is unlikely to improve women's participation in the workforce will not distract us. It would have been convenient to add loss-of-employment to the list of harms that domestic violence causes, but we can do without it. On the other hand, if we are committed to increasing women's participation in the labor force, we need more precise

\footnotetext{
10 " [C]ontrary to expectation, male abuse did not significantly predict current employment status. Women who were victimized by their husbands and boyfriends were employed in roughly the same numbers as those who were not victimized.” [385]
} 
theories about the specific ways that crime-including domestic violence-might systematically interfere with their employment.

As with domestic violence, so with crime more generally. There are lots of good reasons that government should spend money to reduce crime and deliver justice, whether or not that crime stunts economic growth. But if we are committed to spurring economic growth, we need to test our assumptions about the causal links, and focus on the specific ways that we can show crime constrains growth. Most of the assertions in the list of seven are too general for this purpose, conflating the effects of individual victimization, fear of crime, and crime as a symbol of wider government failure. If we want to convert this list of seven into a tighter set of hypotheses on which government can act, we can distil them down to these two:

1. Theft, fraud, corruption, destruction of property, and violent attacks against staff impose direct and indirect costs on businesses that reduce profits, deter new investment, and increase business failures.

2. The perception that violent crime is high and beyond the control of government leads South Africans to restrict their work and leisure activities, restrains investment, and reduces tourism—all of which slow economic growth.

The first of these is a hypothesis about actual crime; the second is a hypothesis about the perception of crime. The first focuses on businesses as victims, the second focuses more generally on the business climate. Each can be tested, and each-if plausible—suggests a series of interventions with which government could experiment.

\section{Reducing the Cost of Crime to Business}

The costs of crime to firms operating in the formal sector of the South African economy appear to be substantial, but not out of line with costs in other middle-income countries. According to the World Bank's Investment Climate Survey, the costs of crime in South Africa for firms at the median are 1.1 percent of sales, 3 percent of net value-added, and 5 percent of labor costs. These are roughly in line with the costs of crime in Brazil, Russia, Peru, and the Philippines.

What distinguishes South Africa from these other middle-income countries is the composition of these costs. South African firms bear more of the costs in direct losses to crime, where the costs in other countries are more heavily weighted toward prevention. Moreover, the prevention costs in South Africa are almost all for security, without the unofficial payments to organized crime or local officials that are common elsewhere. As the World Bank reports:

Few South African firms report that they make unofficial protection payments-a sharp contrast to Eastern Europe and Asia, where firms are often forced to pay police or mafia to avoid being the targets of crime. Direct losses to crime and vandalism in South Africa represent the largest share of total security-associated costs in any of the comparators.... One possible explanation for this is that the 
means by which firms protect themselves from crime are less effective in South Africa. [page 92, figure omitted]

In short, South African firms pay less for security and get less security than firms in other middle income countries. And these costs are growing. According to a recent report, the number of people employed in private security rose by 150 percent from 1997 to 2005. (South African Institute for Race Relations, 2006).

The historically low level of corruption in South Africa may also be changing. In a 2005 survey by PricewaterhouseCoopers of 100 firms (69 of which were listed companies), 36 percent reported corruption or bribery offenses, in contrast to 24 percent globally, and 21 percent in South Africa two years earlier. This apparent increase is in line with more general victimization survey results which, in 2003, found that corruption was the second most frequent form of criminal victimization after housebreaking. The survey found that 5.6 percent of South Africans had been asked for a bribe, favor, or gift from a public official in exchange for a legally required service over a one-year period. A total of 4.6 percent had been asked specifically for cash, up from 2 percent in 1998. Other surveys on corruption have detected a similar rising trend (Burton, et al., 2004).

The problem, in short, is that the costs of crime to businesses in the formal economy are poised to grow higher if firms continue to add security and especially if they begin to make substantial unofficial protection payments. Preventing those costs from growing would be a sensible goal for a range of experimentation in the criminal justice system, but experimentation here should be coordinated with the businesses most important to South Africa's shared growth strategy. For example, if the growth strategy is focused on spurring manufacturing of goods for export, then these are the firms with whom police and justice officials should plan a series of public/private partnerships to halt the growing costs of crime.

\section{The Cost of Crime in the Second Economy}

While most analysis of the costs of crime to business focus on firms in the formal sector, those costs may be more severe for small, medium, and micro enterprises (SMMEs), especially household-based enterprises in low-income settlements. The question of the importance of the informal sector to a South Africa growth strategy lies beyond the scope of this paper. Suffice it to say that many economists believe that small businesses are essential to the innovation and entrepreneurship on which equitable growth depends, and there are others who believe that high growth requires growth in both the first and "second" economy where household-based enterprises predominate. To the extent that the success of these businesses matter to a growth strategy, crime may prove to be a particularly important factor.

The burden of crime on household-based enterprises (HBEs) was demonstrated in a study of such businesses in two, contrasting informal settlements: Mamelodi on the eastern side of Pretoria, South Africa, and Madina on the edge of Accra, Ghana. Researchers selected two sample areas within each of the two settlements, and surveyed every household within those sample areas to identify the extent of HBEs. They found that in Mamelodi, 
40 percent of households had at least one HBE (slightly higher than the 33 percent in Madina). Of the Mamelodi businesses, 73 percent were operated by women, the businesses produced monthly income roughly equal to the minimum wage, and half of the households had no other source of income. More than 90 percent of the HBEs were operated either by a solo proprietor or by family members.

The major difference between the businesses in the two settlements was the impact of crime. The range of businesses (from food service, to retail sales, to services) was similar in Mamelodi and Madina, as were the burdens of financing, competition, and space limitations. But while crime was virtually unknown in Madina, it dominated conversation in Mamelodi. There the researchers found that shops closed early, business had to be conducted indoors - often behind screens, robberies were common, and tenure in the HBEs was short. Many women explained that the small margins were not worth the risk. As the researchers report:

The comparison with the situation in Ghana regarding fear of crime could not be more striking. Many of the HBEs experienced their greatest business after dark when ... the streets are full of people. It is also not uncommon for some HBE operators to have to store their goods outside; for example, a woman who was selling firewood and charcoal had to store her goods on the street but had never experienced any problem with theft at night .... Although it cannot, of course, be claimed that theft and violence are non-existent in Ghana, at no point was the fear of crime mentioned as a factor affecting the operation of the HBEs studied. [p.272]

An analysis of patterns in violent crime by the South African Police Service confirms the high crime rates in Mamelodi. The police station is one of about a dozen that rank in the top tier for robbery, rape, and serious assault. As the World Bank's Investment Climate Survey itself concludes,:”a major crime incident can hit a small firm very hard.” (World Bank, 2005, p. 95).

To address the problem of crime in the second economy, police and justice officials may want to focus on improving safety in the communities where these household-enterprises are most concentrated. Both the police and the National Prosecuting Authority are pursuing programs of community-engagement which could be relatively easily refocused to treat the operators of these businesses as their community partners. A first step might be conduct house-to-house surveys in these communities to document the number, range, and longevity of HBEs, and to establish targets for increasing the longevity of the businesses. Police and prosecutors might even start to calculate a business murder rate, measuring the extent to which theft, burglary, robbery, and other crimes against these marginal businesses forces them to close.

\section{Violent Crime and Confidence in the Criminal Justice System}

When we focus on reducing the actual costs of crime to businesses - whether large firms or household-based enterprises - we play to the strength within justice sector. This is because what we know about crime reduction concerns strategies and tactics to reduce 
specific crimes at specific locations and at specific times. Even this knowledge has huge gaps, but there is evidence that police, prosecutors, and corrections officials can, with some luck, act effectively on specific crime problems.

Now, however, we turn to a wider, more amorphous problem: the likelihood that South Africa's reputation for violent crime is dampening the business climate, leading investors to withhold their capital and leading workers to withhold their labor. There is some tentative statistical evidence for this in South Africa, suggesting that high volumes of crime contribute to general perceptions of government instability which in turn constrain investment, but that crime volume does not exercise an independent influence on economic activity. If a reputation for high levels of violent crime is constraining growth in this or other ways, the challenge is to reduce the perception of crime.

What makes it difficult to manage the perception of crime is that there is no automatic link between the isolated victories that police and justice officials can achieve and the broader perception of crime. In theory, government could address this through advances in crime control, developing strategies for reducing the overall crime rate in the country by substantial proportions. In practice, however, our knowledge of crime control is unequal to this task. The alternative is to focus operations on specific crimes in specific places, and —-when these succeed-leverage them through strategic communications into broader campaigns to restore hope and build confidence in the criminal justice system as a whole.

This two-pronged strategy ignores the problem of the overall crime rate, instead aiming with one prong on specific high-profile crime problems and with the other prong on fear and public confidence. If the first prong fails to solve any specific crime problems, the second prong is merely propaganda; but the problem in South Africa has arguably been the other way around. Police and justice officials have concentrated their efforts on a series of high profile crime problems, such as car-hijacking, bank robbery, and murder in the vicinity of shops that serve or sell liquor, and indeed these specific categories of crime are today far below the rates recorded a few years ago. But leveraging these individual victories into trust and confidence requires clear and coordinated communication. It is not a one-time process but requires that the first small victories be used to begin a cycle in which successes built trust, which in turn helps government achieve more small victories, which again — when effectively communicated - further increase trust. This two-pronged strategy is as much about institutional and political leadership as it is about tactics and strategies for reducing crime.

Such a strategy in South Africa to encourage growth would benefit from more detailed knowledge than currently exists about the levels of confidence in the criminal justice system. Indeed, the most recent general surveys by the Institute for Security Studies in 2003 and by the National Prosecuting Authority in 2005 do not contain a question about confidence in the criminal justice system as a whole, but only ask about confidence in each institution separately. It would also benefit from greater levels of cooperation among the leadership of the component parts of the justice sector than is apparent today. 
The existing survey data on public confidence presents an unusual picture by international standards. Belief that police are doing a good job is lower than typically found in rich countries, but higher than in developing countries. Happily, personal contact with the police more often improves South Africans' impression of the police rather than lowers it, which is the opposite effect that encountering the police produces in England and the United States, for example.

These are strong baselines from which to work, if the generally favorable levels of confidence reported in surveys are true. There are signs, however, that public confidence may be lower than these surveys suggest. For example, the ratio of serious-to-less-serious violent crime reported to the police is unusually high. This is a useful measure of public confidence because the less-serious crimes can generally be assumed to be more numerous, but easier to ignore than more serious crime at any particular level of cynicism. If public confidence is very low, only the most serious crimes in any category will be reported; whereas if public confidence is high, the less serious crimes reported to the police will begin to outstrip the more serious but less frequent crimes. The ratios in South Africa for serious assaults to common assaults reported, for example, are approximately one-to-one. While these ratios tell us very little by themselves, they provide an opportunity to track trends over time, balancing survey with administrative data.

A focus on growth might lead some to suggest that special attention should be paid to the trust and confidence of business operators or investors but the perception of crime among business managers appears to reflect the general level of concern about crime in their communities rather than their direct experience of crime through their business (World Bank, 2005, p. 96).

\section{An Agenda for Policy and Research}

In sum, the careful reader should now be feeling a combination of healthy skepticism about the ability of today's criminal justice system to spur growth and a few ideas for how the system might realistically help. Specifically, there are two broad areas in which efforts at iterative innovation and experimentation seem potentially profitable.

First, the justice sector could try to contain the costs of crime to business. In the formal or "first" economy, this might take the form of a public/private partnership with new and established firms in those sectors - such as manufacturing - targeted for growth. The public and private partners might begin by documenting the losses to crime more thoroughly than was done in the World Bank's investment climate survey (which, for example, asked no questions about insurance). Once the costs themselves and their trajectory are better documented, the resources currently devoted by SAPS to commercial crime, by the National Prosecuting Authority to the experimental commercial courts, and by the Special Investigating Unit to corruption facing companies could all be re-assessed. A new generation of projects should be closely targeted to containing the total costs of crime in key sectors of the ecnomony. 
In the informal or "second" economy, an effort to strengthen community safety in areas with high concentrations of household-based enterprises could make a difference to lowincome communities generally while also supporting a shared growth agenda. Again, starting with careful documentation of the crime problems facing household-based enterprises in low-income settlements would be crucial to the process of rigorous experimentation and iterative innovation. Such a program could aim to achieve measurable results even in the near term, such as longer tenure in business among the mainly female operators. South Africa has had much experience with community safety initiatives over the last ten years, and there is a wealth of lessons on which to draw. This may seem at first to be a police responsibility, but it requires a level of strategic analysis and planning that could be located in any of several government departments and could engage expertise from the business sector as well from prosecution, social welfare, and correctional services.

Second, the leadership of the justice sector departments could work together to build hope and confidence in the justice system. Here, a common set of indicators, drawing on administrative as well as survey data, could provide the basis for taking the currently weak collaboration across the justice cluster to a higher operational and public level. The focus of this initiative, in contrast to the others, might usefully remain on violent crime, particularly murder, robbery, and rape.

Despite the poor state of knowledge about the links between crime and growth, a focused program on these two issues could both loosen some of the restraints on growth in South Africa and contribute to the global understanding of this crucial relationship. In particular, the chance to focus on economic growth in some of the poorest communities, where crime can kill a household business, and to strengthen efforts to build confidence in the justice system as a whole could both provide benefits across South African society. 


\section{References}

Altbeker, Antony (2005) "Paying for crime: South African spending on criminal justice" Institute for Security Studies, Paper 115

Burton, Patrick, Anton Du Plessis, Ted Leggett, Antoinette Louw, Duxita Mistry, Hennie van Vuuren (2004) National Victims of Crime Survey: South Africa 2003, Institute for Security Studies, Monograph 101.

Clegg, Michael, Andrea Finney and Katharine Thorpe (2005) Crime in England and Wales: Quarterly Update to December 2004, Home Office Statistical Bulletin 07/05.

da Mata, Daniel, Uwe Deichmann, J. Vernon Henderson, Somik V. Lall, and Hyoung Gun Wang (2005), Determinants of City Growth in Brazil, World Bank Policy Research Working Paper 3723

Demombynes, Gabriel and Berk Özler (2002), "Crime and Local Inequality in South Africa,” World Bank Policy Research Working Paper 2925.

Glaeser, Edward L. (2005) “The Skilled City” in Taubman Report.

Gough, Katherine V., A. Graham Tipple, and Mark Napier (2003), "Making a Living in African Cities: The Role of Home-based Enterprises in Accra and Pretoria" in International Planning Studies, vol 8, no. 4, pp. 253-277.

Lloyd, Susan (1997) “The Effects of Domestic Violence on Women’s Employment” in Law and Policy, 19:2, pp. 139-167.

Lloyd, Susan, and Nina Tulac (1999), "The Effects of Male Violence on Female Employment” in Violence Against Women, 5:4, pp. 370-392.

Naudé, CMB, JH Prinsloo and JH Martins (1999), “Crimes Against the South African Business Sector" UNICRI.

Newman, Gareth (2005), "A Decade of Crime Prevention in South Africa from National Strategy to Local Challenge,” paper presented at the African Public Safety Conference, Park Hyatt Hotel, Rosebank, Johannesburg, 17-19 August 2005.

PricewaterhouseCoopers (2005) "Global Economic Crime Survey 2005: South Africa”

South Africa Institute of Race Relations (2006), South Africa Survey, as reported by Reuters at http://www.cnn.com/2006/WORLD/africa/04/06/safrica.crime.reut/index.html.

South African Police Service (2003), 2002/2003 Annual Report of the National Commissioner 
Wang, F., and W.W. Minor (2002), "Where the Jobs Are: Employment Access and Crime Patterns in Cleveland" in Annals of the Association of American Geographers; Vol. 92 Issue 3, pp. 435-450

Wilson, James Q. (2004) “Crime and Public Policy” in Wilson and Petersilia (eds.) Crime: Public Policies for Crime Control, Institute for Contemporary Studies

World Bank (2005) South Africa Investment Climate Survey

World Bank (1997) Violence and Urban Poverty in Jamaica: Breaking the Cycle, Human and Social Development Group, Latin America and the Caribbean Region, Report No. 15895-JM. 